\title{
The Ethics of Tax Evasion: A Survey of Chinese Business Students in USA and China
}

\author{
Robert W. McGee \\ Fayetteville State University, Fayetteville, North Carolina
}

Anwar Y. Salimi
University of Laverne

Tax evasion has existed historically. The present study lists rationalizations for tax evasion in a survey consisting of 18 questions.

This survey has been used in the past including a survey of business students in China by McGee, Yoon and Li (2015). The present study surveys Chinese business students studying in the USA and compares the results to the study on Chinese students in China.

The findings of the study indicate that in general both groups of students, those studying in China and those studying in USA, were opposed to tax evasion though for different reasons.

\section{INTRODUCTION}

Tax evasion is an illegal practice and entails an individual, partnership or corporation not paying the true amount of tax that they owe. It involves misrepresentation to avoid showing the correct taxable income of the entity involved. It is punishable by criminal charges and other penalties. Tax evasion is different from tax avoidance which is working within the law to reduce ones tax liability.

Tax evasion has been discussed over the centuries. One of the comprehensive works in this area was written by Martin Crowe, a catholic priest in 1944. Crowe summarized hundreds of years of debate on this topic. His work which was titled The Moral Obligation of Paying Just Taxes presented three philosophical positions on the issue. It identified numerous arguments that have been used to justify tax evasion. The present empirical study takes many of these arguments and uses a survey instrument that is comprised of 18 questions. These questions include questions about respondent's attitude towards tax evasion when taxpayers consider the tax system to be unfair, when tax rates are too high, where taxpayers lack the funds to pay and where the taxes collected are wasted or used for purposes the taxpayers do not agree with. The questionnaire includes arguments used to justify tax evasion in prior studies over the last 500 years.

The present study reports on the results of the survey given to graduate Chinese business students studying in the USA and compares the results to a study of views on tax evasion conducted on Chinese students in China (McGee, Yoon and Li, 2015). The purpose of this study is to see if there is any difference in the results between the two groups of students. The authors would like to thank Yeomin 
Yoon and Ye Li for use of the findings published in McGee, Yoon and Li (2015) for comparison purposes.

The data were analyzed to determine the responses to the 18 historical arguments for tax evasion. Means and standard deviations of responses to the questions were tabulated. The arguments were also ranked from strongest to weakest.

\section{LITERATURE SEARCH}

There have been surveys of Chinese students on the ethics of tax evasion. McGee and Guo (2006) surveyed law, business and philosophy students in Wuhan, China regarding tax evasion. Results indicated that tax evasion was considered unethical if it was for personal reasons but that there was some justification for it if the government was corrupt or the tax system was unfair or when the funds raised from taxes were used in ways that the respondent did not agree with.

Mcgee and An (2007) surveyed business and economics students in Beijing, China regarding tax evasion. The results indicated that tax evasion was not acceptable in most cases except where the money collected was wasted, the tax system was corrupt or unfair, tax rates were too high and beyond the ability of the taxpayer to pay. The sample consisted of both graduate and undergraduate students. Overall there was no significant difference found in the responses regarding tax evasion between the two groups of students.

A study by McGee, Ho and Li (2006) was conducted on comparing the responses of business students in Hong Kong versus American business students in the USA. The study found that while there was agreement that tax evasion was unethical; there were some differences about when it was justified.

McGee and Noronha (2008) compared the opinions of students in Southern China and Macau. They found that overall students from mainland China and Macau were equally opposed to tax evasion.

McGee, Yoon and Li (2014) compared the opinions of Chinese students in China with American students in the USA. The results indicated that Chinese students were significantly more opposed than US students to tax evasion where the statement was that tax evasion was ethical even if the tax rates were not too high, the money was spent wisely, the money was spent on projects I don't approve of or benefit me, if everyone is doing it, probability of getting caught is low, or if the government discriminates against me. Chinese students were less opposed to tax evasion if the money collected was wasted, or if the money was used for wars I consider unjust.

The present study differs from all of the studies mentioned above because it compares the opinions of Chinese students in China and Chinese students studying in the USA who have taken business courses at an American university. Thus any differences between the two groups could have been caused by differences in the educational exposure of the two groups of students.

There have been other surveys regarding tax evasion conducted by McGee and co-authors on other respondent groups all over the world.

\section{METHODOLOGY AND RESULTS}

A survey instrument regarding tax evasion was used to solicit the views of Chinese students studying for a business degree at a university in California. The results were compared to the results of the same survey given to a group of Chinese business students at a university in China. The results for the survey of students in China were obtained with permission from a publication by McGee, Yoon and Li (2014). The statements in the survey are reproduced in Table 1 below. Students were asked to choose a number from 1 to 7 on a Likert scale where $1=$ strongly agree and $7=$ strongly disagree. 
TABLE 1

STATEMENTS IN THE SURVEY INSTRUMENT

\begin{tabular}{|c|l|}
\hline S\# & \\
\hline 1 & Tax evasion is ethical if tax rates are too high. \\
\hline 2 & $\begin{array}{l}\text { Tax evasion is ethical even if tax rates are not too high because the } \\
\text { government is not entitled to take as much as it is taking from me. }\end{array}$ \\
\hline 3 & Tax evasion is ethical if the tax system is unfair. \\
\hline 4 & $\begin{array}{l}\text { Tax evasion is ethical if a large portion of the money collected is } \\
\text { wasted. }\end{array}$ \\
\hline 5 & $\begin{array}{l}\text { Tax evasion is ethical even if most of the money collected is spent } \\
\text { wisely. }\end{array}$ \\
\hline 6 & $\begin{array}{l}\text { Tax evasion is ethical if a large portion of the money collected is } \\
\text { spent on projects that I morally disapprove of. }\end{array}$ \\
\hline 7 & $\begin{array}{l}\text { Tax evasion is ethical even if a large portion of the money collected } \\
\text { is spent on worthy projects. }\end{array}$ \\
\hline 8 & $\begin{array}{l}\text { Tax evasion is ethical if a large portion of the money collected is } \\
\text { spent on projects that do not benefit me. }\end{array}$ \\
\hline 9 & $\begin{array}{l}\text { Tax evasion is ethical even if a large portion of the money collected } \\
\text { is spent on projects that do benefit me. }\end{array}$ \\
\hline 10 & Tax evasion is ethical if everyone is doing it. \\
\hline 11 & $\begin{array}{l}\text { Tax evasion is ethical if a significant portion of the money collected } \\
\text { winds up in the pockets of corrupt politicians or their families and } \\
\text { friends. }\end{array}$ \\
\hline 12 & Tax evasion is ethical if the probability of getting caught is low. \\
\hline 13 & $\begin{array}{l}\text { Tax evasion is ethical if some of the proceeds go to support a war } \\
\text { that I consider to be unjust. }\end{array}$ \\
\hline 14 & Tax evasion is ethical if I cant afford to pay. \\
\hline 15 & $\begin{array}{l}\text { Tax evasion is ethical even if it means that if I pay less, others will } \\
\text { have to pay more. }\end{array}$ \\
\hline 16 & $\begin{array}{l}\text { Tax evasion would be ethical if I were a Jew living in Nazi Germany } \\
\text { in } 1940 .\end{array}$ \\
\hline 17 & $\begin{array}{l}\text { Tax evasion is ethical if the government discriminates against me } \\
\text { because of my religion, race or ethnic background. }\end{array}$ \\
\hline 18 & $\begin{array}{l}\text { Tax evasion is ethical if the government imprisons people for their } \\
\text { political opinions. }\end{array}$ \\
\hline
\end{tabular}


Descriptive statistics for the sample of students in China and the USA are presented in Table 2 below.

TABLE 2

DESCRIPTIVE STATISTICS OF STUDENTS IN CHINA AND USA

\begin{tabular}{|c|c|c|c|c|}
\hline & \multicolumn{2}{|c|}{ CHINA } & \multicolumn{2}{|c|}{ USA } \\
\hline & $\mathrm{n}$ & $\%$ & $\mathrm{n}$ & $\%$ \\
\hline \multicolumn{5}{|l|}{ GENDER } \\
\hline Male & 50 & 25.0 & 9 & $31.03 \%$ \\
\hline Female & 150 & 75.0 & 20 & 68.97 \\
\hline Total & 200 & & 29 & \\
\hline \multicolumn{5}{|l|}{ STUDENT } \\
\hline Undergraduate & 116 & 58.0 & 0 & 0 \\
\hline Year 1 & 51 & 25.5 & & \\
\hline Year 2 & 22 & 11.0 & & \\
\hline Year 3 & 42 & 21.0 & & \\
\hline Year 4 & 1 & 0.5 & & \\
\hline Graduate & 83 & 41.5 & 29 & 100 \\
\hline Year 1 & 75 & 37.5 & & \\
\hline Year 2 & 8 & 4.0 & & \\
\hline Unknown & 1 & 0.5 & & \\
\hline \multicolumn{5}{|l|}{ Other } \\
\hline Total & 200 & & 29 & \\
\hline \multicolumn{5}{|l|}{ MAJOR } \\
\hline Finance & 60 & 30.0 & & \\
\hline Financial engineering & 18 & 9.0 & & \\
\hline Financial management & 14 & 7.0 & & \\
\hline International trade & 44 & 22.0 & & \\
\hline Law & 13 & 6.5 & & \\
\hline Business & 10 & 5.0 & & \\
\hline Other & 41 & 20.5 & & \\
\hline Accounting & & & 29 & 100 \\
\hline \multicolumn{5}{|l|}{ Total } \\
\hline & 200 & & 29 & \\
\hline
\end{tabular}

The results indicate that the two samples are not completely homogenous. The Chinese sample has both graduate and undergraduate students while the US sample has only graduate students. However this may not be a major drawback because a study by McGee and An (2007) mentioned above on tax evasion found that there was no significant difference of opinion between graduate and undergraduate students in 
China. The Chinese sample had a number of different business majors whereas the US sample had only accounting majors.

Table 3 shows the results of the survey for the two groups of students. The mean and standard deviation for each question is shown. A two tailed t test for difference of means was done to compare the means for each question for the true groups. The $t$ value is shown. The last column indicates whether the difference in the mean scores was significant at the 5 percent level.

TABLE 3

RESULTS OF SURVEY OF STUDENTS IN CHINA VERSUS STUDENTS IN USA (1 = STRONGLY AGREE; 7 = STRONGLY DISAGREE)

\begin{tabular}{|c|c|c|c|c|c|c|c|c|}
\hline & \multicolumn{3}{|c|}{ CHINA } & \multicolumn{3}{c|}{ USA } & & \\
\hline S\# & $\mathrm{n}$ & Mean & SD & $\mathrm{n}$ & Mean & SD & $\mathrm{t}$ & $\begin{array}{c}\text { Sign. } \\
\text { viff? }\end{array}$ \\
\hline 1 & 200 & 5.145 & 1.896 & 29 & 5.51724 & 1.5950 & -1.00636 & NO \\
\hline 2 & 200 & 6.010 & 1.503 & 29 & 5.41379 & 1.4019 & 2.01253 & YES \\
\hline 3 & 200 & 4.475 & 1.921 & 29 & 4.34483 & 1.9689 & 0.33997 & NO \\
\hline 4 & 199 & 4.226 & 2.109 & 29 & 4.72414 & 1.7907 & -1.2094 & NO \\
\hline 5 & 199 & 6.397 & 1.283 & 29 & 6.06897 & 1.2516 & 1.2902 & NO \\
\hline 6 & 200 & 5.950 & 1.303 & 29 & 5.48276 & 1.4298 & 1.78165 & NO \\
\hline 7 & 200 & 6.390 & 1.352 & 29 & 5.72414 & 1.3335 & 2.48274 & YES \\
\hline 8 & 200 & 6.130 & 1.298 & 29 & 5.62069 & 1.2932 & .00211 & NO \\
\hline 9 & 200 & 6.485 & 1.221 & 29 & 5.86207 & 1.3816 & 2.52428 & YES \\
\hline 10 & 200 & 6.190 & 1.544 & 29 & 5.48276 & 1.5725 & 2.29995 & YES \\
\hline 11 & 200 & 4.515 & 2.204 & 29 & 4.93103 & 2.0862 & -.95586 & NO \\
\hline 12 & 200 & 6.450 & 1.174 & 29 & 5.93103 & 1.5336 & 2.13363 & YES \\
\hline 13 & 198 & 3.965 & 2.191 & 29 & 4.86207 & 1.8268 & -2.09941 & YES \\
\hline 14 & 199 & 5.050 & 2.027 & 29 & 5 & 1.5811 & .12722 & NO \\
\hline 15 & 199 & 6.322 & 1.239 & 29 & 6.03448 & 1.1796 & 1.1743 & NO \\
\hline 16 & 199 & 4.085 & 2.323 & 29 & 5.51724 & 1.7852 & -3.18367 & YES \\
\hline 17 & 199 & 4.497 & 2.196 & 29 & 4.65517 & 2.1090 & -.36413 & NO \\
\hline 18 & 199 & 3.935 & 2.222 & 29 & 5.39286 & 1.4991 & -3.36237 & YES \\
\hline
\end{tabular}


Table 4 lists the differences in the survey results for the two groups of students.

TABLE 4

DIFFERENCES IN SURVEY FOR THE STUDENTS IN CHINA VERSUS USA

\begin{tabular}{|l|l|}
\hline & S\# \\
\hline Chinese were significantly more opposed to tax evasion & $2,7,9,10,12$ \\
\hline Chinese were more opposed to tax evasion, but not significantly & $3,5,6,8,14,15$ \\
\hline Chinese were less opposed to tax evasion, but not significantly & $1,4,11,17$ \\
\hline Chinese were significantly less opposed to tax evasion & $13,16,18$ \\
\hline
\end{tabular}

The results in Table 5 show the statements on which the China sample was significantly more opposed to tax evasion

TABLE 5

STATEMENTS FOR WHICH CHINESE WERE SIGNIFICANTLY MORE OPPOSED TO TAX EVASION

\begin{tabular}{|c|c|}
\hline S\# & \\
\hline 2 & $\begin{array}{r}\text { Tax evasion is ethical even if tax rates are not too high because the } \\
\text { government is not entitled to take as much as it is taking from me. }\end{array}$ \\
\hline 7 & $\begin{array}{c}\text { Tax evasion is ethical even if a large portion of the money collected is spent } \\
\text { on worthy projects. }\end{array}$ \\
\hline 9 & $\begin{array}{r}\text { Tax evasion is ethical even if a large portion of the money collected is spent } \\
\text { on projects that do benefit me. }\end{array}$ \\
\hline 10 & Tax evasion is ethical if everyone is doing it. \\
\hline 12 & Tax evasion is ethical if the probability of getting caught is low. \\
\hline
\end{tabular}

Table 6 lists the questions on which the students in China were significantly less opposed to tax evasion than the students in the USA.

TABLE 6

CASES WHERE CHINESE WERE SIGNIFICANTLY LESS OPPOSED TO TAX EVASION

\begin{tabular}{|c|c|}
\hline S\# & \\
\hline 13 & $\begin{array}{r}\text { Tax evasion is ethical if some of the proceeds go to support a war that I consider to be } \\
\text { unjust. }\end{array}$ \\
\hline 16 & Tax evasion would be ethical if I were a Jew living in Nazi Germany. \\
\hline 18 & Tax Evasion is ethical if the government imprisons people for their political opinions. \\
\hline
\end{tabular}


Table 7 lists the rankings for the various statements for the two groups of students:

\section{TABLE 7 \\ RELATIVE RANKING OF REASONS FOR JUSTIFYING TAX EVASION (1 = MOST OPPOSED; 18 = LEAST OPPOSED)}

\begin{tabular}{|c|c|l|}
\hline CHINA & USA & \\
\hline 1 & 4 & $\begin{array}{l}\text { Tax evasion is ethical even if a large portion of the money } \\
\text { collected is spent on projects that do benefit me. }\end{array}$ \\
\hline 2 & 3 & $\begin{array}{l}\text { Tax evasion is ethical if the probability of getting caught } \\
\text { is low. }\end{array}$ \\
\hline 3 & 1 & $\begin{array}{l}\text { Tax evasion is ethical even if most of the money collected } \\
\text { is spent wisely. }\end{array}$ \\
\hline 4 & 5 & $\begin{array}{l}\text { Tax evasion is ethical even if a large portion of the money } \\
\text { collected is spent on worthy projects. }\end{array}$ \\
\hline 5 & 2 & $\begin{array}{l}\text { Tax evasion is ethical even if it means that if I pay less, } \\
\text { others will have to pay more. }\end{array}$ \\
\hline 6 & 10 & Tax evasion is ethical if everyone is doing it. \\
\hline 7 & 6 & Tax evasion is ethical if a large portion of the money \\
\hline 8 & 11 & Tax evasion is ethical even if tax rates are not too high \\
\hline 9 & 9 & Tax evasion is ethical if a large portion of the money \\
\hline 10 & 7 & Tax evasion is ethical if tax rates are too high. \\
\hline 11 & 13 & Tax evasion is ethical if I cant afford to pay. \\
\hline 12 & 14 & Tax evasion is ethical if a significant portion of the money \\
\hline 13 & 17 & Tax evasion is ethical if the government discriminates \\
\hline 14 & 18 & Tax evasion is ethical if the tax system is unfair. \\
\hline 15 & 16 & Tax evasion is ethical if a large portion of the money \\
\hline 16 & 8 & Tax evasion would be ethical if I were a Jew living in \\
\hline 17 & 15 & Tax evasion is ethical if some of the proceeds go to \\
\hline 18 & 12 & Tax evasion is ethical if the government imprisons people \\
\hline
\end{tabular}

The results are somewhat similar but the statements on which there was a difference in ranking of more than 2 were the following. The students in China ranked their opposition to tax evasion relatively higher even if the money was spent on projects that did not benefit me, if everyone was doing it, because the government is not entitled to take so much in taxes, or if the government discriminates against me. The students in USA were relatively more opposed to tax evasion, even if it meant others would have to pay more, even if tax rates are too high, if I were a Jew living in Nazi Germany and if the government imprisons people for their political opinions.

\section{CONCLUSION}

The findings of the survey indicate that both the students surveyed in China and in USA opposed tax evasion. But there were some significant differences among the two groups about the extent to which they opposed some of the statements regarding tax evasion. The group in China ranked their opposition to tax evasion relatively higher on those statements which said that tax evasion was justified if the money was 
spent on projects that did not benefit me, if everyone was doing it, because the government is not entitled to take so much in taxes, or if the government discriminates against me.

The group surveyed in the USA was more opposed to tax evasion on those statements which said that tax evasion is justified if it meant others would have to pay more, if tax rates are too high, if I were a Jew living in Nazi Germany and if the government imprisons people for their political opinions.

Both groups were opposed to tax evasion overall. The differences in opposition to particular statements on the survey may be due to the differences in educational exposure of the two groups of students with one group studying in China and the other group studying in the USA.

\section{REFERENCES}

Crowe, M. T. (1944). The Moral Obligation of Paying Just Taxes, Unpublished doctoral dissertation, The Catholic University of America Studies in Sacred Theology No. 84.

McGee, R. W. and Yuhua An. (2008). A Survey of Chinese Business and Economics Students on the Ethics of Tax Evasion, in Robert W. McGee, editor, Taxation and Public Finance in Transition and Developing Economies, 409-421. New York: Springer.

McGee, R. W. and Guo, Z. (2007). A Survey of Law, Business and Philosophy Students in China on the Ethics of Tax Evasion. Society and Business Review 2(3): 299-315.

McGee, R. W., Ho, S.M. and Li, A.Y.S. (2008). A Comparative Study on Perceived Ethics of Tax Evasion: Hong Kong vs. the United States. Journal of Business Ethics 77(2): 147-158.

McGee, R.W. and Noronha, C. (2008). The Ethics of Tax Evasion: A Comparative Study of Guangzhou (Southern China) and Macau Opinions. Euro Asia Journal of Management 18(2): 133-152.

McGee, R.W., Yoon, Y. and Li, Y. The Ethics of Tax Evasion: A Comparative Study of Chinese and U.S. Opinions. Indonesian Journal of International \& Comparative Law, 2(1): 161-186 (2015). 